\section{CELLS IN EVOLUTION}

Cytology and Evolution

By Dr. E. N. Willmer. Pp. $x+430$. (New York : Academic Press, Inc.; London : Academic Press. Ine. (London), Ltd., 1960.) $70 s$.

$\mathrm{T}$ HIS is a scholarly work, for Dr. Willmer has given thought to his subject for many years. Inevitably, it is not an easy book to read and assimilate. Cytology and Evolution is a challenging title; at one extreme, it is concerned with the techniques required to reveal the nature of cellular physiology, and at the other, the infinitely complicated problem of cell evolution in higher organisms. Characteristically, Dr. Willmer introduces the subject by visualizing "the conversion of the Victorian carriage into the racing car of to-day" as a lesson in evolution. $\mathrm{H}_{\theta}$ is intrigued by "the mystery of a common organiza. tion", and his argument opens by examining the similarity in the fine structure of cilia throughout the lower and higher forms of life.

The author knows as much as anyone could about the behaviour of cells isolated from their normal environment and grown in tissue culture. From his experience, he has developed the interesting simplification that tissue culture encourages the growth of three stem-lines of cells. These are the epitheliocytes, the mechanocytes, and the amobocytes, and the photographs selected are most effective in illustrating his point of view.

The book begins its own organic growth with the definition of these different cell forms, and here the reader meets the first complications in the argument. What, the author has asked himself, are the morphological and physiological features which define an epitheliocyte, a mechanocyte, and an amobocyte? Many examples can be cited which apparently define or separate one cell from another, such as the strange phenomenon that an epitheliocyte will be unaffected by the death of its neighbour (punctured through his nucleus), while a fibroblastic cell will choose to die along with its neighbouring cell. There is also the problem of the permanent cell lines which have been maintained for many years in tissue culture and which appear to have become a 'classless' society.

The basic ideas of the author take up one-third of the book ; their effect on the analysis of embryogenesis is developed in the remaining two-thirds of the book. Dr. Willmer takes the reader as gently as possible through the reversible transformation of flagellate cell types to amoboid cell types, as found in certain lower organisms, particularly Naegleria, on which he has himself done fascinating work. One reader, at least, is concerned that he has chosen only to discuss the transformations in terms of homoiostasis, and does not envisage, for example, the possibility that the ionic environment might alter the templates for enzyme formation within the cell.

In developing his theme, Dr. Willmer seems at first to be 'Lamarckian' rather than 'Darwinian' in his outlook. $\mathrm{He}$ instances the fact that "many animals independently under Arctic conditions cease to produce melanin in their skins, and so all become white", and evidently considers this to be an adaptation to the iciness of their environment instead of natural selection. How else can one construe the observation on the same page (227) that "when phenyl-alanine is added to tissue cultures of even the ventral ectoderm, the cells of which would never normally produce melanin, some of these cells can actually be induced to do so"? Perhaps it is only a lapse in analogy, for clearly the author favours natural selection when he later describes the disadvantages of "poor form-vision under critical conditions of hunting or being hunted".

In discussing the development of the kidneys, gonads, adrenal cortex, and other cell populations closely related to them, he envisages their origin from the colomoducts and the nephridia of the more primitive invertebrates. This last third of the book is a mine of valuable information hidden in catacombs of unresolved definition and delineation. When, for example, at page 274, the reader finds that the nephron of kidney tissue would best be described as "some sort of nephromixium", he later has to try to understand why the spermatic tubules and their mesonephric elements should be described as a "mixonephridium".

Appropriately the book ends on the subject of light and evolution of vision, and the final chapter is an illuminating summary of the author's concepts of evolutionary cytology. Here, Dr. Willmer states concisely the principles on which he bases his view about the evolution of cell types and embryogenesis. As a cytologist he treats cell structure with reverence and appears to be horrified by the butchery involved in the biochemical analysis of sub-cellular fractions. Nevertheless, the book concludes that there is an exciting 'jungle pathway' ahead for microbiochemistry and cellular physiology. Dr. Willmer has done a great service by creating a new and well-indexed route through the jungle of cytological embryology.

I. LESLIE

\section{A SURVEY OF EXTRA-SENSORY PERCEPTION}

The Hidden Springs

An Enquiry into Extra-Sensory Perception. By Renée Haynes. Pp. $264+9$ plates. (London : Hollis and Carter, Ltd., 1961.) 30s. net.

LTHOUGH this book is said on the title-page to be an inquiry into extra-sensory perception, it is much more a descriptive historical summary than an inquiry. Miss Haynes, writing from the point of view of a Roman Catholic, traces the belief in extra-sensory perception from early times, showing how the faculty was believed to exist and how it was described and became a part of various theological and philosophical systems. Passing from the supposed appearance of extra-sensory perception in animals, insects, etc., Miss Haynes proceeds to describe its occurrence and treatment among people in ancient, medieval and modern times, and traces the story from the days of the Roman Augurs to the late Prof. Jung's theory of synchronicity.

This book, like others on the same subject recently published, illustrates a trend in psychical research which is becoming increasingly apparent. Although there have been some trenchant criticisms of some of the more famous and supposedly 'water-tight' experiments, the tendency is to ignore and belittle such work and to proclaim that extra-sensory perception is now an established fact, and that, as Miss Haynes puts it, resistance to the idea springs from dread of the acute intellectual discomfort involved in recognizing its implications, a feeling which would be new to many scientific men. What the author fails to 